\title{
PENGARUH BIAYA PAKAN TERHADAP KEUNTUNGAN PETERNAK BABI DI DESA WERDHI AGUNG KECAMATAN DUMOGA BARAT
}

\author{
Chrestian C Matialo, F.H Elly*, S Dalie, B Rorimpandey \\ Fakultas Peternakan Universitas Sam Ratulangi
}

\begin{abstract}
ABSTRAK
Usaha ternak babi sebagai sumber pendapatan peternak di Desa Werdhi Agung Kecamatan Dumoga Barat. Kendala yang dihadapi adalah keterbatasan modal yang berdampak terhadap pengeluaran biaya pakan. Penelitian ini bertujuan untuk pengaruh biaya pakan terhadap keuntungan peternak babi. Metode yang digunakan adalah metode survey terhadap 30 responden peternak babi di Desa Werdhi Agung Kecamatan Dumoga Barat, dengan penentuan sampel dilakukan secara purposive sampling yaitu pengambilan sampel secara sengaja dengan petimbangan peternak memiliki ternak babi di atas 20 ekor dan pengalamam beternak lebih dari 1 tahun. Metode analisis yang digunakan dalam penelitian ini adalah analisis regresi linear berganda. Hasil penelitian menujukkan bahwa total biaya produksi rata-rata $\mathrm{Rp}$ 44.349.066, penerimaan $\mathrm{Rp} 92.320,667$ dan keuntungan $\mathrm{Rp}$ 47.971.601 per peternak per periode. Secara simultan biaya konsentrat, dedak dan jagung berpengaruh nyata terhadap keuntungan peternak babi. Berdasarkan hasil penelitian dapat disimpulkan bahwa rata-rata biaya pakan yang dikeluarkan peternak sebesar $\mathrm{Rp}$ 32.466 .933 per periode $(73,21$ persen dari total biaya produksi). Secara parsial biaya
\end{abstract}

\footnotetext{
*Korespondensi (Corresponding author):

Email: femihelly@unsrat.ac.id
}

konsentrat berpengaruh sangat nyata terhadap keuntungan peternak babi di Desa Werdhi Agung Kecamatan Dumoga Barat.

Kata Kunci : Biaya, pakan, keuntungan

\section{ABSTRACT}

THE EFFECT OF FEED COST ON THE PROFIT OF PIG FARMERS IN WERDHI AGUNG VILLAGE, WEST DUMOGA DISTRICT. This study aims to determine influence of feed cost on pig farmer's profits. This research was conducted by survey method to 30 respondents of pig farmers in werdhi agung village, west dumoga subdistrict. The determination of samples was carried out by purposive sampling, with the consideration of breeders have pig over 20 heads and more than one year experienced on pig farm. The analytical method used in this study was multiple linear regression analysis. Study results showed the cost of consentrate feed, bran, corn, had significantly effect on the profits of pig farmers simultaneously Partially the cost of concentrate had a very significant effect, while the cost of ingredient feed materials of bran, corn, had no significant effect on profits.

Keywords: Feed cost, profit, pig farm. 


\section{PENDAHULUAN}

Indonesia memiliki ternak babi yang telah dikembangkan oleh masyarakat pedesaan. Keberagaman spesies babi yang ada di Indonesia terbukti dengan ditemukannya empat alel yang berbeda dan merupakan jumlah alel mitokondria tertinggi yang telah ditemukan (Choi et al., 2014). Data Ditjen PKH (2013) menunjukkan bahwa populasi ternak babi terkonsentrasi pada beberapa daerah diantaranya di Bali, Sumatera, Jawa, Bali, Kalimantan, Nusa Tenggara Timur (NTT), Sulawesi dan Papua. Banyaknya populasi ternak babi dapat dijadikan salah satu sumber daging bagi sekitar $13 \%$ penduduk Indonesia (Ditjen PKH, 2013).

Ternak babi merupakan salah satu sumber pendapatan bagi peternak babi di "Indonesia" termasuk peternak babi di Sulawesi Utara, khususnya di Desa Werdhi Agung. Sariubang dan Kaharuddin (2011) bahwa di Kabupaten Tana Toraja memiliki peluang untuk pengembangan usaha ternak babi. Hal ini disebabkan karena ternak babi merupakan salah satu usaha yang efisien sebagai sumber pendapatan petani peternak. Proses produksi usaha ternak babi lebih mudah dan memiliki prosepek pemasaran yang luas. Ternak babi adalah suatu usaha yang dapat menghasilkan daging disamping dapat menghasilkan pupuk organik dan biogas (Utomo dan Wahyuningsih, 2010; Seseray et al., 2012).

Kelebihan ternak babi adalah sebagai salah satu jenis ternak mamalia yang menghasilkan anak dalam jumlah besar (litter size). Selain itu, jarak antar kelahiran lebih singkat dibandingkan ternak lainnya seperti domba, sapi, kerbau dan kuda. Kelebihan tersebut berdampak terhadap tingginya potensi reproduksi sehingga pertambahan populasi dan pertumbuhannya lebih cepat. Ternak babi dalam hal ini dapat dijadikan sebagai salah satu sumber daging, khususnya pada masyarakat yang mengkonsumsi daging babi seperti di provinsi Sulawesi Utara.

Peternak babi dalam mengembangkan usahanya membutuhkan modal. Peternak yang memiliki keterbatasan modal tentunya berdampak terhadap skala usaha pemeliharaan dan penggunaan faktor input. Kondisi ini berdampak terhadap tingkat keuntungan yang cenderung menurun. Disisi lain, keberlangsungan usaha peternakan babi tergantung pada harga input dan harga output. Fluktuasinya harga input berdampak terhadap biaya produksi usaha ternak babi. Kenaikan biaya produksi tanpa diikuti dengan kenaikan harga output menjadi kendala bagi peternak babi. 
Perubahan harga faktor produksi yang cenderung meningkat berdampak terhadap perubahan keuntungan yang diterima peternak babi. Padahal, peternak babi menjalankan usahanya dengan harapan keuntungan yang diperoleh maksimum. Kenyataan menunjukkan bahwa keberhasilan usaha peternakan babi sangat tergantung dari keuntungan yang diperoleh peternak babi.

Desa Werdhi Agung Kecamatan Dumoga Barat adalah salah satu daerah yang memiliki peternak babi yang telah digeluti bertahun-tahun. Peternakan babi yang dikelola peternak di daerah tersebut berperan sebagai sumber protein hewani dan sebagai sumber pendapatan peternak. Permasalahannya fluktuasinya harga input berdampak terhadap ketidakkontinyunya usaha ternak babi yang dijalankan peternak di daerah tersebut. Harga input yang cenderung meningkat menyebabkan biaya produksi semakin meningkat. Biaya produksi dimaksud diantaranya biaya pakan. Sihombing (2010), biaya produksi terbesar adalah biaya pakan ternak babi yang mencapai 65-80 persen dari total biaya produksi. Hal ini disebabkan karena bahan pakan ternak babi merupakan faktor produksi utama dalam usaha peternakan babi. Kuantitas dan kualitas bahan pakan berpengaruh terhadap pertumbuhan ternak babi. Menurut (Budaarsa et al., 2016), jumlah pakan yang diberikan pada ternak babi harus disesuaikan dengan umur dan berat badan ternak babi. Ternak babi umur 8-10 minggu rata-rata pakan 0,83 , umur 12-20 minggu rata-rata 1.62, umur 21-29 minggu rata-rata $2,74 \mathrm{~kg} /$ hari/ekor. Ternak babi induk menyusui rata-rata pakan 2,50 dan ternak pejantan rata-rata 2,35 kg/ekor/hari.

Berdasarkan hasil pra survey di Desa Werdhi Agung Kecamatan Dumoga Barat, bahan pakan yang diberikan yaitu konsentrat, dedak dan jagung. Permasalahannya berapa besar biaya produksi yang dikeluarkan peternak babi yang berdampak terhadap keuntungan mereka. Selain itu, apakah biaya konsentrat, dedak dan jagung memberikan dampak terhadap penurunan keuntungan peternak babi. Berdasarkan permasalahan tersebut maka telah dilakukan penelitian untuk menganalisis pengaruh biaya pakan terhadap keuntungan peternak babi di Desa Werdhi Agung Kecamatan Dumoga Barat.

\section{METODE PENELITIAN}

Penelitian ini dilaksanakan di Desa Werdhi Agung Kecamatan Dumoga Barat, dengan metode yang digunakan adalah survey dengan menggunakan daftar pertanyaan. Metode penentuan 
sampel lokasi secara purposive sampling dengan pertimbangan bahwa lokasi penelitian tersebut memiliki jumlah peternak babi mencapai $30 \%$ dari keseluruhan jumlah KK. Penentuan responden secara purposive sampling sebanyak 30 responden dengan pertimbangan bahwa peternak babi memiliki ternak di atas 20 ekor dan usaha ternak babi sudah berlangsung lebih dari 1 tahun. Data yang digunakan dalam penelitian yaitu data primer dan data sekunder. Data primer diperoleh dari hasil wawancara kepada peternak babi. Data sekunder penelitian ini diperoleh dari studi literatur dan instansi yang terkait dengan penelitian ini. Variabel yang diukur dalam penelitian ini yaitu biaya produksi ternak babi adalah keseluruhan biaya-biaya yang dikeluarkan dalam proses produksi pemeliharaan ternak babi, terdiri dari biaya tetap dan biaya variabel, diukur dalam satuan rupiah per periode. Biaya tetap terdiri dari biaya kandang, peralatan dan biaya transportasi. Biaya variabel terdiri dari biaya pakan, tenaga kerja, obat-obatan dan listrik. Biaya pakan terdiri dari biaya konsentrat, dedak dan jagung. Penerimaan ialah nilai uang dari jumlah satuan ternak yang dipelihara maupun dijual, dinyatakan dalam satuan rupiah per periode. Keuntungan atau pendapatan usaha ternak babi adalah seluruh penerimaan dikurangi dengan biaya produksi, diukur dalam satuan rupiah per periode. Analisis data yang digunakan adalah analisis deskriptif dan analisis fungsi regresi berganda. Secara matematis model fungsi linear berganda dapat ditulis seperti persamaan (1) (Gupito et al., 2014; Rochaeni et al., 2014).

$\mathrm{Y}=\mathrm{a}+\mathrm{b}_{1} \mathrm{X}_{1}+\mathrm{b}_{2} \mathrm{X}_{2}+\mathrm{b}_{3} \mathrm{X}_{3}+\mathrm{e}_{\mathrm{i}}$

Keterangan :

$$
\begin{array}{ll}
\mathrm{Y} & =\text { Keuntungan (Rp/periode) } \\
\mathrm{a} & =\text { Intersep (perpotongan) } \\
\mathrm{b}_{\mathrm{i}} & =\text { Koefisien regresi } \\
\mathrm{e}_{\mathrm{i}} & =\text { Faktor penganggu } \\
\mathrm{X}_{1} & =\text { Konsentrat (Rp/periode) } \\
\mathrm{X}_{2} & =\text { Dedak (Rp/tahun) } \\
\mathrm{X}_{3} & =\text { Jagung (Rp/tahun) }
\end{array}
$$

\section{HASIL PENELITIAN DAN PEMBAHASAN}

Unsur-unsur karakteristik yang dikumpulkan dari responden dalam penelitian ini antara lain umur, tingkat pendidikan, pengalaman beternak dan pekerjaan utama. Karakteristik responden sesuai hasil penelitian dapat dilihat pada Tabel 1.

Umur responden 15-55 tahun yaitu 24 orang (80 persen) sedangkan responden golongan usia tidak produktif > 55 tahun yaitu 6 orang (20 persen) dari jumlah 
responden (Tabel 1). Secara umum diaplikasikan dalam mengelola usaha responden termasuk kedalam golongan ternak babi. Menurut Kueain et al. (2017) usia produktif. Kondisi ini menunjukkan pekerja yang mampu bekerja dengan bahwa peternak sebagai responden kemampuan yang tinggi dapat memiliki kemampuan dalam mengadopsi meningkatkan usaha peternakan babi. inovasi sehingga mudah untuk

Tabel 1. Karakteristik Responden Peternak Babi di Desa Werdhi Agung Kecamatan Dumoga Barat.

\begin{tabular}{|c|c|c|c|}
\hline \multirow[t]{2}{*}{ No } & \multirow[t]{2}{*}{ Karakteristik } & \multicolumn{2}{|c|}{ Jumlah Responden } \\
\hline & & Orang & Persentasi (\%) \\
\hline \multirow[t]{4}{*}{1} & Umur (Tahun) & & \\
\hline & $15-55$ & 24.00 & 80.00 \\
\hline & $>55$ & 6.00 & 20.00 \\
\hline & Total & 30.00 & 100.00 \\
\hline \multirow[t]{6}{*}{2} & Tingkat Pendidikan & & \\
\hline & SD & 9.00 & 30.00 \\
\hline & SMP & 6.00 & 20.00 \\
\hline & SMA & 14.00 & 46.67 \\
\hline & Perguruan Tinggi & 1.00 & 3.33 \\
\hline & Total & 30.00 & 100.00 \\
\hline \multirow[t]{4}{*}{3} & Pengalaman Beternak (Tahun) & & \\
\hline & $1-15$ & 25.00 & 83.33 \\
\hline & $16-27$ & 5.00 & 16.67 \\
\hline & Total & 30.00 & 100.00 \\
\hline \multirow[t]{6}{*}{4} & Pekerjaan & & \\
\hline & Petani & 15.00 & 50.00 \\
\hline & Peternak & 6.00 & 20.00 \\
\hline & PNS & 3.00 & 10.00 \\
\hline & Wiraswasta & 6.00 & 20.00 \\
\hline & Total & 30.00 & 100.00 \\
\hline
\end{tabular}


Pendidikan dapat diperoleh secara formal seperti di bangku sekolah maupun non formal seperti kursus atau pelatihan. Tingkat pendidikan responden sesuai hasil penelitian adalah pendidikan formal. Data Tabel 1 menunjukkan bahwa tingkat pendidikan paling banyak adalah tamatan SMA yang berjumlah 14 orang (46.67 persen), SD berjumlah 9 orang (30 persen), SMP berjumlah 6 orang (20 persen), Perguruan tinggi berjumlah 1 orang (3.33 persen). Pendidikan yang dimiliki oleh seorang akan membedakan orang tersebut dengan mereka yang tidak memiliki pendidikan. Tingkat pendidikan di daerah penelitian masih dikategorikan rendah karena sebagian besar masih pada tingkat SMA dan dibawahnya.

Hasil penelitian menunjukkan bahwa pengalaman beternak responden bervariasi mulai dari 2 sampai 27 tahun. Data pada Tabel 1 menunjukkan bahwa peternak yang memiliki pengalaman beternak 1-15 tahun yaitu 25 orang (83.33 persen) dan 16-27 tahun yaitu 5 orang (16.67 persen). Hasil penelitian menunjukkan bahwa sebagian besar responden memiliki pengalaman yang lama dalam beternak babi sehingga responden dapat mampu menghadapi masalah dan menyesuaikan dengan situasi perekonomian. Peternak dapat mencari solusi dalam mencari alternatif khususnya bahan pakan ternak babi yang lebih efisien dan efektif.

Jenis pekerjaan responden berbedabeda, petani adalah jumlah responden terbanyak yaitu 15 orang (50 persen), diikuti sebagai peternak dan wiraswata masing-masing 6 orang (20 persen) dan PNS 3 orang (20 persen) jumlah responden terendah. Data Tabel 1 menunjukkan sebagai besar responden beternak babi sebagai usaha sambilan (Paramata et al., 2016). Usaha ternak babi dilakukan sebagai sumber pendapatan untuk kebutuhan keluarga dalam membiayai anak sekolah dan kebutuahan hidup keluarga mereka.

Biaya produksi merupakan sejumlah biaya yang dikeluarkan oleh peternak untuk mendapatkan keuntungan. Biaya produksi yang dikeluarkan peternak terdiri dari biaya tetap dan biaya variabel (Tabel 2). Biaya produksi terbesar berasal dari biaya variabel yaitu sebesar Rp. 1.024.630.000 (77.02 persen dari total biaya produksi). Besarnya biaya variabel (biaya tidak tetap) disebabkan karena biaya ini tergantung dari besar kecilnya jumlah produksi ternak babi. Biaya variabel peternak yang menjual anak babi dalam satu tahun usaha adalah 73,94 persen, sedangkan yang menjual babi penggemukan 97,18 persen (Lalus et al., 2019). Biaya variabel didefinisikan sebagai 
biaya yang dikeluarkan atau ditanggung oleh peternak selama masa produksi yang besar kecilnya dipengaruhi oleh skala atau jumlah produksi. Skala produksi yang semakin tinggi berdampak terhadap semakin meningkat biaya variabel yang harus ditanggung oleh peternak selama masa produksi berlangsung. Biaya variabel menurut penelitian Asmie dan Poniwati (2008) dan Sukanata et al. (2017), terdiri dari pengeluaran untuk sarana produksi biaya pakan, tenaga kerja, obatobatan/vaksin, dan biaya listrik.

Biaya produksi merupakan penjumlahan biaya tetap dan biaya variabel. Tabel 2 menunjukkan biaya produksi yang terbesar yaitu biaya pakan sebesar Rp. 973.938 .000 (73,21 persen).
Biaya paling rendah adalah biaya transportasi yaitu Rp. $2.442 .000 \quad(0,18$ persen dari total biaya produksi). Hal ini sesuai dengan penelitian Aritonang (2010), bahwa biaya pakan mempunyai persentase terbesar dari keseluruhan biaya produksi yaitu berkisar 60-80 persen.

Biaya pakan pada penelitian ini terdiri dari biaya pembelian konsentrat, dedak dan jagung. Pakan sebagai konsumsi ternak babi di daerah penelitian dicampur sendiri oleh peternak dengan tujuan untuk meminimalkan biaya pakan. Biaya konsentrat, dedak dan jagung dapat dilihat pada Tabel 3. Biaya tertinggi adalah biaya untuk konsentrat $(39,83$ persen $)$ kemudian diikuti biaya jagung (38,21 persen).

Tabel 2. Biaya Produksi Usaha Ternak Babi di Desa Werdhi Agung Kecamatan Dumoga Barat

\begin{tabular}{|c|c|c|c|}
\hline Jenis Biaya Produksi & $\begin{array}{c}\text { Total } \\
\text { (Rp/Periode) } \\
\end{array}$ & $\begin{array}{c}\text { Rata-rata }(\mathrm{Rp} / \\
\text { Periode/Peternak) }\end{array}$ & $\begin{array}{c}\text { Prosentase } \\
(\%)\end{array}$ \\
\hline \multicolumn{4}{|l|}{ Biaya Tetap } \\
\hline -Kandang & 290.500 .000 & 9.683 .333 & 21,84 \\
\hline -Peralatan & 12.830 .000 & 427.667 & 0,96 \\
\hline -Transportasi & 2.442 .000 & 81.400 & 0,18 \\
\hline \multicolumn{4}{|l|}{ Biaya Variabel } \\
\hline - Pakan & 973.938 .000 & 32.466 .933 & 73,21 \\
\hline - Tenaga Kerja & 42.300 .000 & 1.410 .000 & 3,18 \\
\hline - Obat-obatan & 2.850 .000 & 95.000 & 0,21 \\
\hline - Listrik & 5.542 .000 & 184.733 & 0,42 \\
\hline Total Biaya Produksi & 1.330 .402 .000 & 44.349 .066 & 100,00 \\
\hline
\end{tabular}


Tabel 3. Biaya Pakan Usaha Ternak Babi di Desa Werdhi Agung Kecamatan Dumoga Barat

\begin{tabular}{lcrr}
\hline $\begin{array}{c}\text { Jenis Bahan Pakan dan } \\
\text { Biaya }\end{array}$ & $\begin{array}{c}\text { Total } \\
\text { (Rp/Periode) }\end{array}$ & $\begin{array}{c}\text { Rata-rata (Rp/ } \\
\text { Periode/Peternak) }\end{array}$ & $\begin{array}{c}\text { Prosentase } \\
(\%)\end{array}$ \\
\hline Biaya Konsentrat & 387.969 .000 & 12.932 .300 & 39,83 \\
Biaya Dedak & 213.851 .000 & 7.128 .367 & 21,96 \\
Biaya Jagung & 372.118 .000 & 12.403 .933 & 38,21 \\
\hline \multicolumn{1}{c}{ Total } & 973.938 .000 & 32.464 .600 & 100,00 \\
\hline
\end{tabular}

Penerimaan dalam penelitian ini adalah semua hasil penjualan ternak babi dalam hal ini jumlah produksi dikali harga. Hal ini sejalan dengan Soekartawi (2003), bahwa penerimaan usahatani tunai didefinisikan sebagai nilai uang yang diterima dari penjualan pokok usahatani.

Keuntungan peternak dalam penelitian ini adalah selisih antara hasil penjualan (penerimaan) dengan total biaya produksi. Total penerimaan, biaya produksi dan keuntungan peternak babi di daerah penelitian dinyatakan dalam Tabel 4.
Tabel 4 menunjukan bahwa ratarata peternak mempunyai penerimaan ratarata Rp. 92.320.667 per periode pemeliharaan dan rata-rata keuntungan adalah Rp. 49,376,600. per periode. Keuntungan bisa ditingkatkan apabila peternak dapat menekan biaya produksi. Hasil suatu proses produksi tidak lepas dari penggunaan biaya pakan sebagai salah satu komponen biaya produksi yang mempengaruhi keuntungan.

Tabel 4. Biaya Produksi, Penerimaan dan Keuntungan Ternak Babi di Desa Werdi Agung Kecamatan Dumoga Barat.

\begin{tabular}{lrr}
\hline \multicolumn{1}{c}{ Uraian } & Total (Rp/periode) & \multicolumn{1}{c}{$\begin{array}{c}\text { Rata-rata } \\
\text { (Rp/periode/peternak) }\end{array}$} \\
\hline Total Biaya Produksi & 1.330 .402 .000 & 44.349 .066 \\
Penerimaan & 2.769 .620 .000 & 92.320 .667 \\
Keuntungan & 1.439 .218 .000 & 47.971 .601 \\
\hline
\end{tabular}


Pengaruh biaya pakan terhadap keuntungan dianalisis dengan menggunakan analisis regresi berganda. Hasil analisis regresi diringkas dalam persamaan regresi berikut.

$$
\begin{gathered}
Y=146.318+4.130 X_{1}-3.900 X_{2}+ \\
1.217 X_{3}+e
\end{gathered}
$$

Berdasarkan persamaan regresi masing-masing variabel dapat digambarkan pengaruhnya terhadap keuntungan peternak babi Desa Werhi Agung Kecamatan Dumoga Barat. Hasil analisa regresi diperoleh koefisien regresi $\mathrm{X}_{1}$ (konsentrat) sebesar 4.130, dan $\mathrm{X}_{3}$ (jagung) sebesar 1.217, artinya apabila $X_{1}$ (konsentrat) dan $\mathrm{X}_{3}$ (jagung) naik sebesar Rp. 1 maka Y (keuntungan) akan naik sebesar Rp 4.130 dan Rp. 1.217. Semakin tinggi biaya yang dikeluarkan menyebabkan keuntungan semakin berkurang (Elly dan Umboh, 2017). Berbeda dengan hasil penelitian ini naiknya biaya pakan konsentrat dan jagung masih meningkatkan keuntungan. Hal ini karena komposisi bahan baku pakan telah dimodifikasi oleh peternak.

Koefisien regresi $\mathrm{X}_{2}$ (dedak) sebesar $-3,900$ artinya apabila biaya dedak naik $\operatorname{Rp} 1$ mengakibatkan penurunan keuntungan sebesar Rp 3,900. Hasil ini sejalan dengan teori semakin besar biaya produksi yang dikeluarkan berdampak terhadap keuntungan. Dedak di daerah penelitian cukup berlimpah sehingga biasanya peternak membeli dengan lebih murah. Apabila harga dedak naik berdampak mengurangi keuntungan, sehingga peternak dapat menggunakan pakan alternatif seperti yang dinyatakan (Paramarta et al., 2016), kenaikan harga jual pakan ternak dapat diatasi dengan penyedian pakan alternatif.

Nilai koefisien determinasi $\mathrm{R}^{2}(\mathrm{R}$ square) sebesar 0,601. Artinya variasi naik turunnya keuntungan 60 persen ditentukan oleh biaya konsentrat, dedak dan jagung. Sisanya 30,7 persen dipengaruhi oleh faktor lain yang tidak termasuk dalam analisis ini. Hasil pengujian dengan menggunakan uji $\mathrm{F}$ menunjukkan bahwa secara simultan biaya pakan kosentrat, dedak, jagung. berpengaruh sangat nyata terhadap keuntungan $(\alpha=0.000)$. Secara parsial (menggunakan uji-t), menunjukkan biaya pakan konsentrat, berpengaruh nyata ( $\alpha=0.048)$ sedangkan biaya pakan dedak dan jagung berpengaruh tidak nyata terhadap keuntungan $(\alpha=0.357)$ dan $(\alpha=$ $561)$.

\section{KESIMPULAN}

Berdasarkan hasil penelitian dapat disimpulkan bahwa rata-rata biaya pakan yang dikeluarkan peternak sebesar Rp 32.466 .933 per periode $(73,21$ persen dari 
total biaya produksi). Secara parsial biaya konsentrat berpengaruh sangat nyata terhadap keuntungan peternak babi di Desa Werdhi Agung Kecamatan Dumoga Barat.

\section{DAFTAR PUSTAKA}

Asmie, Poniwati. 2008 Analisis faktorfaktor yang mempengaruhi tingkat pendapatan pedagangpasar tradisional di Kota Yogyakarta. Jurnal Ekonomi. 3 (6) : 85-97

Budaarsa, K., A.W. Puger dan I M. Suasta. 2016. Eksplorasi komposisi pakan tradisional babi bali. Majalah Ilmiah Peternakan, 6-11.

Choi, S.K., L.J. Eun., K.Y. Jun., M.M. Sook., I. Voloshina., A. Myslenkov., J.G. Oh., K.T. hun., N. Markov, and I. Seryodkin. 2014. Genetic structure of wild boar (Sus scrofa) populations from East Asia based on microsatellite loci analyses. Jurnal BMC Genet. 15 (3) : $1-10$.

Ditjen PKH. 2013. Statistik peternakan dan kesehatan hewan 2013. Jakarta (Indonesia): Direktorat Jenderal Peternakan dan Kesehatan Hewan.

Elly, F.H dan S.J.K. Umboh. 2017. Teori Ekonomi Produksi. Lembaga Pembinaan dan Pengembangan Pembelajaran Universitas Sam Ratulangi, Manado.

Gupito, R.W., Irham dan L.R. Waluyati, 2014. Analisis faktor-faktor yang mempengaruhi usaha tani sorgum di Kabupaten Gunung Kidul. Jurnal Agro Ekonomi 24 (1): 66-75.

Kueain, Y.A., I.K. Suamba dan P.U. Wijayanti. 2017. Analisis finansial usaha peternakan babi (Studi Kasus Peternakan Babi UD Karang di Desa Jagapati, Kecamatan Abiansemal, Kabupaten Badung). E-jurnal Agribisnis dan Agrowisata $6(1)$ : 96-104.
Lalus, N.F., J.G. Sogen dan S.M. Makan dolu. 2019. Analisis pendapatan usaha ternak babi dari dua cara penjualan yang berbeda di Kota Kupang. Jurnal Peternakan Lahan Kering 1 (4) : 671-677.

Paramarta, I.P.T., I.M. Antara dan P.U. Wijayanti. 2016. Kelayakan usaha ternak babi di UD Sindi Mandiri Desa Bongan Kecamatan Tabanan Kabupaten Tabanan. E-jurnal Agribisnis dan Agrowisata 5 (2) : 370-379.

Rochaeni, S., E. Daris dan Hanafi, 2014. Analisis faktor-faktor yang mempengaruhi permintaan tempe di Kelurahan Jurang Mangu Timur Pondok Aren Tangerang Selatan. Jurnal Agribisnis 8 (1): 1 - 14.

Sariubang M dan Kaharuddin. 2011. Analisis ekonomi pemeliharaan ternak babi secara tradisional di Kabupaten Tana Toraja, Sulawesi Selatan. J Agrisistem. 7 (1) : 115122.

Seseray, D.Y.S., S. Triatmojo dan A. Pertiwiningrum. 2012. Pemanfaatan feses babi (Sus sp.) sebagai sumber gas bio dengan penambahan ampas sagu (Metroxylon spp.) pada taraf rasio $\mathrm{C} / \mathrm{N}$ ratio. Jurnal Agrisains 36 (3) : 66-74.

Sihombing, D.T.H. 2010. Ilmu Ternak Babi. Gadjah Mada University Press Yokyakarta.

Soekartawi A, 2003. Teori Ekonomi Produksi Dengan Pokok Bahasan Analisis Fungsi Cobb-Douglas. Cetakan ke-3. PT. Raja Grafindo Persada. Jakarta. Hal. 14.

Sukanata, I.W., B.R.T. Putri., Suciani dan I.G. Suranjaya. 2017. Analisis pendapatan usaha penggemukan babi Bali yang menggunakan pakan komersial (Studi Kasus di Desa Gerokgak-Buleleng). 
Majalah Ilmiah Peternakan 20 (2): 60-63.

Utomo, S. dan V. Wahyuningsih. 2010. Dosis campuran limbah sapi dengan limbah babi terhadap produksi gas bio. Jurnal AgriSains 1

7-14. 